\title{
Functional Properties of Food Proteins Polymerized by Transglutaminase
}

\author{
Masao Motoki, Noriki Nio, Koichi Takinami \\ Central Research Laboratories, Ajinomoto Co., Inc., \\ Suzuki-cho, Kawasaki-ku, Kawasaki 210, Japan
}

Received October 17, 1983

\begin{abstract}
The following properties of food proteins polymerized by guinea pig liver transglutaminase were investigated: (1) solubility, (2) emulsifying activity and emulsion stability, and (3) unfrozen water content by pulsed NMR. Several food proteins $\left(\alpha_{s 1}-\right.$ and $\kappa$-caseins, and soybean $7 \mathrm{~S}$ and $11 \mathrm{~S}$ globulins) were polymerized by this enzyme. Solubility and emulsifying activity of polymerized $\alpha_{s 1}$. casein were higher than those of the native protein in the range of $\mathrm{pH} 4 \sim 6$. Unfrozen water contents of polymerized soybean globulins were much higher than those of the native proteins. These results suggest that transglutaminase treatment may be used for the production of new food protein material with higher hydration ability.
\end{abstract}

Transglutaminase ( $R$-glutaminyl-peptide: amine $\gamma$-glutamyltransferase; EC 2.3.2.13) was found to catalyze the acyl transfer reaction between the $\gamma$-carboxyl groups of glutaminyl residues in proteins and a variety of primary amines. ${ }^{1,2)}$ When protein-bound lysyl residues act as acyl receptors, intra- and intermolecular $\varepsilon$-( $\gamma$-glutamyl)lysine isopeptide crosslinks are formed by the enzyme reaction.

Whitaker ${ }^{3)}$ suggested that it would be useful to investigate the possibility of using transglutaminase for the formation of the crosslinks in protein leading to textured products. Recently Ikura et al. reported that transglutaminase polymerized bovine casein components ${ }^{4)}$ and soybean proteins ${ }^{5)}$ forming the intermolecular crosslinks. It was further shown that transglutaminase catalyzed the crosslinking reaction between different food proteins. ${ }^{6}$ )

These investigations confirmed the possibilities that transglutaminase would be used for the production of new textured products by the formation of the crosslinks. Very few papers have appeared describing the estimation of the functional properties of food proteins polymerized by transglutaminase, althrough the $\mathrm{Ca}^{2+}$-binding ability of the polymerized caseins was described in the abovementioned report of Ikura et al. ${ }^{4)}$ The present paper describes some functional properties of the food proteins $\left(\alpha_{\mathrm{s} 1}-\right.$ and $\kappa$-caseins, and soybean 7S and 11S globulins) polymerized by the guinea pig liver transglutaminase.

\section{MATERIALS AND METHODS}

Transglutaminase. Transglutaminase was prepared from fresh guinea pig livers by the method of Connellan et al. ${ }^{7)}$ During the purification, the enzyme activity of the fractionated and the purified samples was determined respectively by the colorimetric procedure, in which the detectable hydroxamate was formed, using $N$-carbobenzoxyL-glutaminylglycine. ${ }^{8)}$ The method of Lowry et al. ${ }^{9)}$ was used to determine the enzyme concentration. The purified enzyme gave a single band on polyacrylamide gel electrophoresis in the presence of sodium dodecyl sulfate (SDS-PAGE) and a single peak on high-performance liquid chromatography (TSK-GEL G3000SW column). Eight hundred grams of guinea pig livers yielded $118 \mathrm{mg}$ of transglutaminase preparation with a specific activity of $12.7 \mathrm{unit} / \mathrm{mg}$. The enzyme solution was stored at $-30^{\circ} \mathrm{C}$ in $10 \mathrm{~mm}$ Tris-acetate buffer (pH 6) containing 1 mM EDTA and $0.16 \mathrm{M} \mathrm{KCl}$.

Protein substrates. $\alpha_{\mathrm{s} 1}$ - and $\kappa$-caseins were prepared from fresh milk by the method of Zittle and Custer. ${ }^{10)}$ Crude $11 \mathrm{~S}$ and $7 \mathrm{~S}$ globulins were prepared from defatted soybean flour by the method of Thanh et al. ${ }^{11)}$ The obtained crude globulins were then chromatographed on a Sepharose $6 \mathrm{~B}$ column (Pharmacia Fine Chemicals) at $5^{\circ} \mathrm{C}$. These protein solutions were dialyzed overnight against distilled water, and then lyophilized. 
Polymerization of proteins by crosslinking. The proteincrosslinking reaction was carried out by the modified method of Ikura et al. ${ }^{4}$ A protein solution $(5 \mathrm{mg} / \mathrm{ml})$ was prepared in a $0.1 \mathrm{~m}$ Tris- $\mathrm{HCl}(\mathrm{pH} 7.5)$ buffer containing $5 \mathrm{mM} \mathrm{CaCl}_{2}$ and $10 \mathrm{~mm}$ dithiothreitol. Ninety $\mu \mathrm{g}$ of transglutaminase were added to $1.0 \mathrm{ml}$ of this protein solution. After incubating for $4 \mathrm{hr}$ at $37^{\circ} \mathrm{C}$, the reaction mixtures were extensively dialyzed against distilled water. The dialysates were lyophilized and stored at room temperature.

Solubility. A mixture of proteins $(15 \mathrm{mg})$ and McIlvaine buffer $(5 \mathrm{ml}, \mathrm{pH} 3.0 \sim 8.0)$ was vigorously shaken for $3 \mathrm{~min}$ on a shaker. The resulting suspension was centrifuged at $3000 \mathrm{rpm}$ for $10 \mathrm{~min}$ at room temperature. The protein concentration in the supernatant was determined by using a protein assay kit (Bio Rad Laboratories). The solubility was calculated as the ratio of the soluble protein of the supernatant to the total protein in the initial suspension.

Measurement of emulsifying activity and emulsion stability. The emulsifying activity was measured by the modified turbidimetric technique of Yamauchi et al., ${ }^{12)}$ which is based on the method of Pearce and Kinsella. ${ }^{13)}$ A $1 \%$ protein solution was prepared in a potassium phosphate buffer ( $\mathrm{pH} 8.0, \mu=0.1$ ). The protein solution $(1.4 \mathrm{ml})$ was added to $0.6 \mathrm{ml}$ of soybean oil placed in a test tube $(11 \times 130 \mathrm{~mm})$ and was sonicated with a horntype adaptor (6 $\mathrm{mm}$ diameter) fitted to a sonifier (Ohtake Seisakusho, Model 5202, $20 \mathrm{kHz}$ ) at $60 \mathrm{~W}$ power for $3.0 \mathrm{~min}$, cooling in an ice-water bath. The same phosphate buffer $(8 \mathrm{ml})$ was added to the emulsion $(2 \mathrm{ml}$, the first dilution). An aliquot $(0.02 \mathrm{ml})$ of the first diluted emulsion was further diluted with $10 \mathrm{ml}$ of $0.1 \%$ SDS solution (the second dilution). The turbidity of the second diluted emulsion was measured in a cuvette of $10 \mathrm{~mm}$ optical path at the wavelength of $500 \mathrm{~nm}$ with a spectrophotometer (Hitachi, model 320). The turbidity corresponds to the emulsifying activity.

In order to estimate the emulsion stability, the first diluted emulsion described above was also permitted to stand for $24 \mathrm{hr}$ at room temperature. A portion $(2 \mathrm{ml})$ of the emulsion was taken from the bottom and the moisture content was analyzed after lyophilization. The emulsion stability is defined by the following equation:

$$
\text { Emulsion stability }=\frac{100-M \text { test }}{100-M \text { original }} \times 100(\%)
$$

where $M$ test is the percent moisture of the bottom $2 \mathrm{ml}$ of the sample stored for $24 \mathrm{hr}$ and $M$ original is the initial percent moisture of the sample.

Measurement of unfrozen water content. The unfrozen water content of the proteins was measured by an automatic recording system, using a broad-line pulsed NMR spectrometer (Brucker, Minispec P 20) and minicomputer (Hewlett-Packard, HP 1000), developed by Suzuki and Nagashima. ${ }^{14)}$ Each sample of $60 \mathrm{mg}$ of the protein was stuffed into a $6.8 \mathrm{~mm}$ inner diameter glass tube with $140 \mu \mathrm{l}$ of distilled water. This protein suspension was at first cooled and then warmed at the rate of $3^{\circ} \mathrm{C} / \mathrm{min}$ with liquid nitrogen and gaseous one. The value of the unfrozen water content was indicated as a dry basis, i.e. gram of water per gram of dry matter (g- $\mathrm{H}_{2} \mathrm{O} / \mathrm{g}-\mathrm{D} . \mathrm{M}$.), using the dry matter value obtained by drying a sample for $8 \mathrm{hr}$ at $115^{\circ} \mathrm{C}$.

Gel electrophoresis. Polyacrylamide gel electrophoresis was performed on slab gels in the presence of sodium dodecyl sulfate (SDS) as described in the previous paper. ${ }^{6)}$

\section{RESULTS AND DISCUSSION}

\section{Formation of crosslinked protein}

The reaction products were analyzed by SDS polyacrylamide gel electrophoresis to confirm the formation of polymers through the intermolecular crosslinks catalyzed by transglutaminase. Figure 1 shows that as the reaction proceeded the monomer fraction diminished or disappeared, while the polymer fraction increased conversely. The reaction mixture treated by transglutaminase for $4 \mathrm{hr}$ was dialyzed against distilled water and followed by lyophilization. The obtained proteins were subjected to the following experiments.

\section{Solubility}

Figure 2 shows the solubility of the native and the polymerized proteins at various $\mathrm{pH}$ values. The apparent $\mathrm{p} I$ of the polymerized proteins hardly changed, compared with the native proteins. The solubility of polymerized $\alpha_{\mathrm{s} 1}$-casein was increased in the range of $\mathrm{pH} 4 \sim 6$. But there was little change in the solubility between polymerized $\kappa$-casein and the native version. On the other hand, for the polymerized $11 \mathrm{~S}$ and $7 \mathrm{~S}$ globulins their solubilities decreased. Especially, polymerized $11 \mathrm{~S}$ globulin was scarcely dissolved at various $\mathrm{pH}$ values. It seems that the increments of carboxyl groups, which form ion bridges with $\varepsilon-\mathrm{NH}_{3}^{+}$before transglutaminase reaction, result in higher solubility in general. Contrarily, soybean globulins have a 

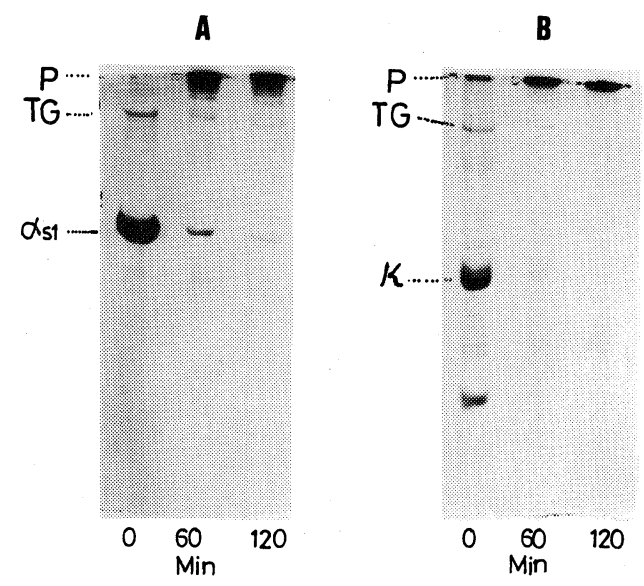

C

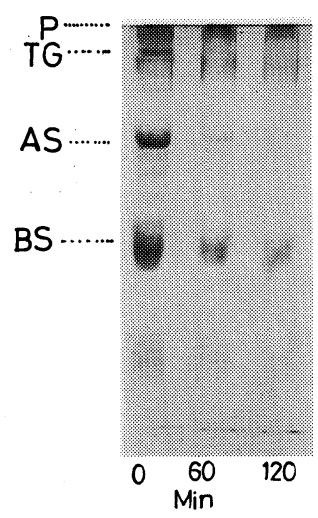



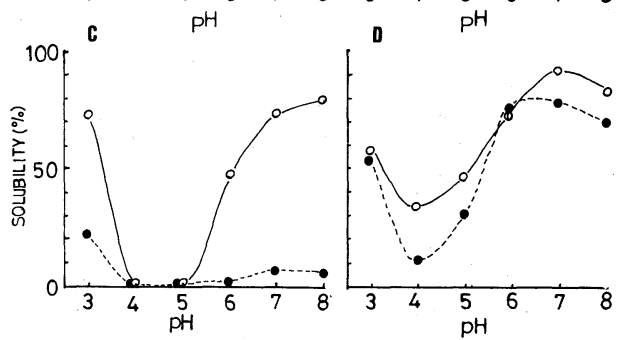

Fig. 2. $\mathrm{pH}$-solubility Profiles of Native (-O-) and Polymerized (-----) Proteins.

(A) $\alpha_{\mathrm{s} 1}$-casein; (B) $\kappa$-casein; (C) $11 \mathrm{~S}$ globulin; (D) $7 \mathrm{~S}$ globulin.

the oil particles give lower turbidities, ${ }^{12)}$ the lower turbidity of the polymerized proteins $(\kappa-$ casein and $11 \mathrm{~S}$ and $7 \mathrm{~S}$ globulins) seemed to be due to their formation of large clusters. On the other hand, native $\alpha_{\mathrm{s} 1}$-casein may form particles larger than those of the modified proteinstabilized emulsion owing to the formation of a soluble polymer by self-association. As shown in Fig. 4, the emulsion stabilities of the polymerized proteins were lower than those of the native proteins. It is considered that the lower solubilities at $\mathrm{pH} 8.0$ of the polymerized proteins (Fig. 2) resulted in lower emulsion stabilities.

\section{Hydration properties}

The freezing and thawing curves (Fig. 5) show that the polymerized and the native protein suspensions were entirely different in their hydration properties. The unfrozen water content at $-30^{\circ} \mathrm{C}$, which corresponds to a tightly-bound water content, and signal vanishing temperature are shown for several proteins in Table I. Except $\alpha_{\mathrm{s} 1}$-casein, all the other polymerized proteins have higher unfrozen water values than those of each native protein. However, the polymerized proteins more quickly reached the signal vanishing emulsion, except for the case of $\alpha_{\mathrm{s} 1}$-casein (Fig. 3). Since larger particles and/or flocculation of

\section{Emulsifying properties}

The turbidities of each polymerized proteinstabilized emulsion were lower than those of the corresponding native protein-stabilized 


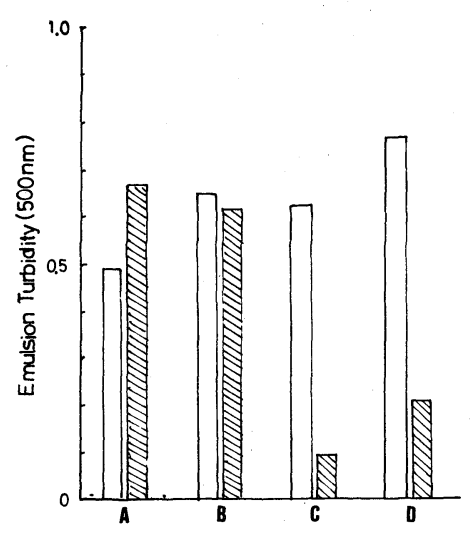

FIG. 3. Emulsifying Turbidity of Native ( $\square$ ) and Polymerized ( एव: ) Protein.

A, $\alpha_{\mathrm{s} 1}$-casein; B, $\kappa$-casein; C, $11 \mathrm{~S}$ globulin; D, 7S globulin.

A

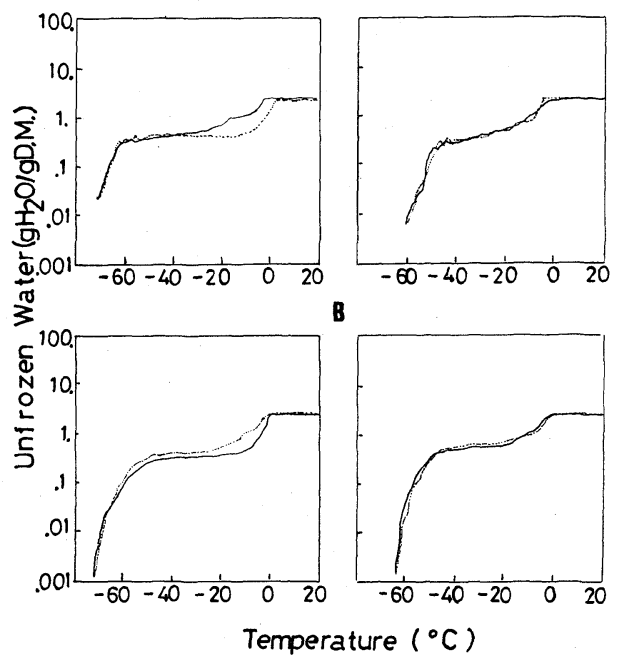

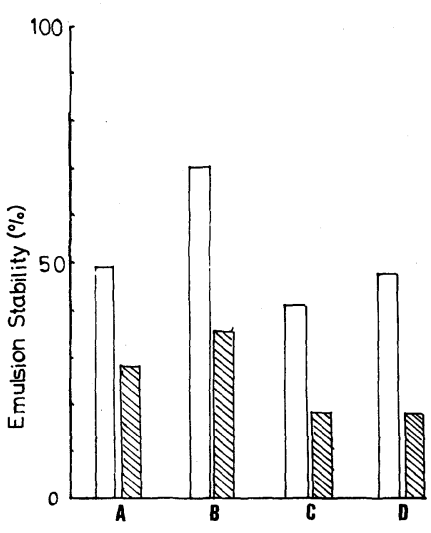

FIG. 4. Emulsion Stability of Native $(\square)$ and Polymerized ( Protein.

A, $\alpha_{\mathrm{s} 1}$-casein; $\mathrm{B}, \kappa$-casein; C, $11 \mathrm{~S}$ globulin; D, 7S globulin.
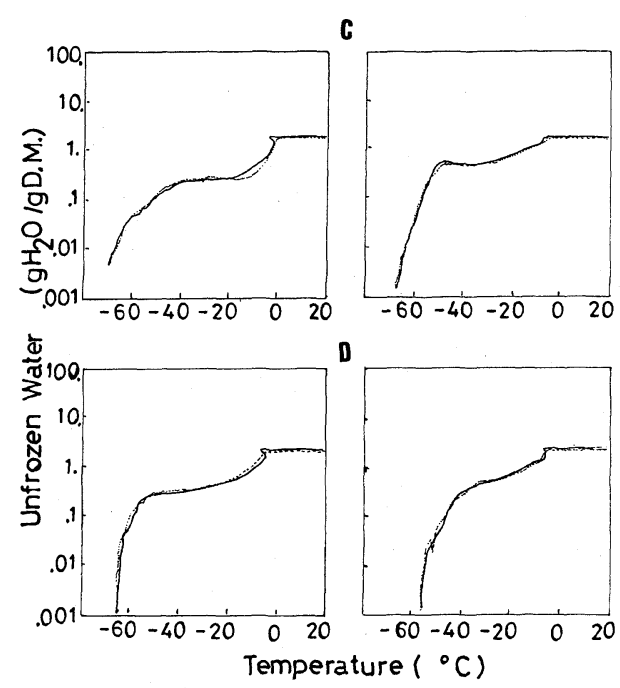

FIG. 5. Freezing (-) and Thawing (-----) Curves of Native (Left) and Polymerized Protein (Right).

(A) $\alpha_{\mathrm{s} 1}$-casein; (B) $\kappa$-casein; (C) $11 \mathrm{~S}$ globulin; (D) $7 \mathrm{~S}$ globulin.

temperature and had no hysteresis. It is thought that water-binding may be caused by any of the following properties: (a) the ability to swell and take up water; (b) a high viscosity caused by soluble molecules, swollen particles or a mixture of the two; (c) the ability to form a gel network during processing. ${ }^{16)}$ Native $\alpha_{\mathrm{s} 1}$ casein exists as a self-associate and its suspension has a high viscosity. It fits the case (b). The freezing-thawing curve of native $\alpha_{s 1}$-casein (Fig. 5A) shows a large hysteresis loop. The unfrozen water content of gelatin, which forms an aqueous gel, was much higher and the freezing-thawing curve had a remarkably large hysteresis loop (Table I). It is thought that water molecules in the gelatin gel are structured in a gel network (matching case (c)). In the case of the polymerized products by transglutaminase, their freezing-thawing properties indicated that the water binding is considered to be dependent on the ability to swell and take up water (matching case (a)), 
Table I. Unfrozen Water Content and Signal Vanishing Temperature of Native and Polymerized Proteins

\begin{tabular}{|c|c|c|c|c|}
\hline \multicolumn{2}{|c|}{ Protein } & \multirow{2}{*}{$\frac{\mathrm{UFW}\left(\mathrm{g}-\mathrm{H}_{2} \mathrm{O} / \mathrm{g}-\mathrm{D} . \mathrm{M} .\right)}{0.414}$} & \multirow{2}{*}{$\frac{\operatorname{SVT}\left({ }^{\circ} \mathrm{C}\right)}{-72}$} & \multirow{2}{*}{$\frac{\text { Hysteresis }}{\text { medium }}$} \\
\hline & Sative & & & \\
\hline$\alpha_{\mathrm{s} 1}-$ casein & Polymer & 0.401 & -52 & none \\
\hline \multirow{2}{*}{$\kappa$-Casein } & $\{$ Native & 0.384 & -70 & small \\
\hline & Polymer & 0.561 & -63 & none \\
\hline \multirow{2}{*}{ 11S Globulin } & $\{$ Native & 0.239 & -68 & small \\
\hline & Polymer & 0.561 & -63 & none \\
\hline \multirow{2}{*}{ 7S Globulin } & SNative & 0.427 & -68 & small \\
\hline & Polymer & 0.457 & -55 & none \\
\hline Gelatin & Native & 0.600 & -77 & large \\
\hline
\end{tabular}

UFW, unfrozen water content $\left(\mathrm{g}-\mathrm{H}_{2} \mathrm{O} / \mathrm{g}\right.$-dry matter) at $-30^{\circ} \mathrm{C}$. SVT, signal vanishing temperature, the temperature at which the apparent unfrozen water content becomes lower than $0.01 \mathrm{~g}-\mathrm{H}_{2} \mathrm{O} / \mathrm{g}$-dry matter. The values for native proteins $\left(\alpha_{\mathrm{s} 1}\right.$-casein, $11 \mathrm{~S}$ globulin and gelatin) were same as reported previously. ${ }^{14)}$

not on a gel network and high viscosity.

In conclusion, transglutaminase treatment brought on various changes in the functional properties. Especially it is the most significant result that the hydration abilities of the polymerized proteins were greater than those of the native proteins. Thus transglutaminase may be used for the production of some new food protein materials through the formation of the crosslinks. For example, such modified proteins with high hydration ability may be available for the production of intermediate moisture protein foods.

\section{REFERENCES}

1) J. E. Folk and S. I. Chung, "Advance in Enzymology," Vol. 38, ed. by A. Meister, John Wiley \& Sons Inc., New York, N. Y., 1973, p. 109.

2) J. E. Folk and J. S. Finlayson, "Advances in Protein Chemistry," Vol. 31, ed. by C. B. Anfinsen, J. T. Edsall and F. M. Richards, Academic Press Inc., New York, N. Y., 1977, p. 1.

3) J. R. Whitaker, "Food Proteins-Improvement through Chemical and Enzymatic Modification," ed. by R. E. Feeney and J. R. Whitaker, American Chemical Society, 1977, p. 95.

4) K. Ikura, T. Kometani, M. Yoshikawa, R. Sasaki and H. Chiba, Agric. Biol. Chem., 44, 1567 (1980).

5) K. Ikura, T. Kometani, R. Sasaki and H. Chiba, Agric. Biol. Chem., 44, 2979 (1980).

6) M. Motoki and N. Nio, J. Food Sci., 48, 561 (1983).

7) J. H. Connellan, S. I. Chung, N. K. Whetzel, C. M. Bradley and J. E. Folk, J. Biol. Chem., 246, 1093 (1971).

8) J. E. Folk and P. W. Cole, J. Biol. Chem., 241, 5518 (1966).

9) O. H. Lowry, N. J. Rosebrough, A. L. Farr and R. J. Randall, J. Biol. Chem., 193, 265 (1951).

10) C. A. Zittle and J. H. Custer, J. Dairy Sci., 46, 1183 (1963).

11) V. H. Thanh, K. Okubo and K. Shibasaki, Plant Physiol., 56, 19 (1975).

12) F. Yamauchi, Y. Ogawa, Y. Kamata and K. Shibasaki, Agric. Biol. Chem., 46, 615 (1982); Y. Ogawa, F. Yamauchi and K. Shibasaki, Nippon Shokuhin Kogyo Gakkaishi, 27, 631 (1980).

13) K. N. Pearce and J. E. Kinsella, J. Agric. Food Chem., 26, 716 (1978).

14) E. Suzuki and N. Nagashima, Bull. Chem. Soc. Jpn., 55, 2730 (1982).

15) K. Ikura, M. Yoshikawa, R. Sasaki and H. Chiba, Agric. Biol. Chem., 45, 2587 (1981).

16) A. M. Hermansson, J. Am. Oil Chem. Soc., 56, 272 (1979). 